\title{
Physicochemical properties and sensory acceptance of biscuits fortified with Plantago psyllium flour
}

\author{
Magdalena Krystyjan ${ }^{1 *}$, Dorota Gumul', Anna Korus ${ }^{2}$, Jarosław Korus ${ }^{1}$, Marek Sikora ${ }^{1}$ \\ ${ }^{1}$ Department of Carbohydrates Technology, Faculty of Food Technology, University of Agriculture in Krakow, Poland, ${ }^{2}$ Department of Fruit, \\ Vegetable and Mushroom Technology, University of Agriculture in Krakow, Poland
}

\section{A B S TR A C T}

\begin{abstract}
The aim of this work was to fortified biscuits with psyllium flour obtained from Plantago psyllium seeds and checked how this additive, reach in fibre and mucilage, had the impact on the physical, mechanical and sensory parameters of biscuits. The following addition psyllium flour was applied: $5,10,15$ and $20 \%$ in relation to wheat flour. The moisture, texture, volume, spreadability factor, volume as well as texture, color and sensory assessment of biscuits were determined. The applied fortification contributed to increase the spreadability of biscuits and the decrease in their volume and hardness. According to consumers, the best sensory attributes received biscuits with $5 \%$ addition of psyllium flour, and higher levels of the additive had a negative impact on their sensory assessment.
\end{abstract}

Keywords: Biscuits; Plantago psyllium; Physicochemical properties; Sensory analysis; Texture

\section{INTRODUCTION}

Biscuits belong to the group of the most frequently eaten pastry products. They owe their popularity to availability, long shelf life and, above all, rich diversity, both in terms of appearance and taste. The biscuits dough may be produced with such ingredients as: flour, fat, sugar, milk, eggs, salt, starch, cocoa, leaving agents, emulsifiers as well as essences (Tireki 2008). In the present day, the main aim is to enrich pastry products with ingredients rich in protein, fibre, vitamins or antioxidant compounds (Chauhan et al. 2015, Čukelj et al. 2017, Krystyjan et al. 2015a, Korus et al. 2017, Mesías et al. 2016, Pasqualone et al. 2014). There were also known attempts to reduce the energy value of such products by eliminating or substituting fat (Rodríguez-García et al. 2013, Krystyjan et al. 2015a, Laguna et al. 2012) and sugar (Aggarwal et al. 2016, Savitha et al. 2008, Zoulias 2002). Such treatments allow obtaining a healthy and more attractive product for the consumer.

Plantago psyllium seeds have been used for a long time, mainly in pharmaceutical industry (Craeyveld et al. 2009, Singh 2007) and to a smaller extent also in the food processing plants. There are known attempts to use it as additives in burgers and beef sausage production (Osheba et al. 2013) and for obtaining starch-based edible films (Krystyjan et al. 2017). This raw material was used in cookie production as the form of psyllium fibre (Raymundo et al. 2014). The aim of this work was to fortify biscuits with psyllium flour obtained from grounded Plantago psyllium seeds rich not only in fibre but also in mucilage presented in the seed husk (Craeyveld et al. 2009, Guo et al. 2008). This flour has the ability to absorb water contained in the product. Such property can have a significant impact on the physical, mechanical and sensory parameters of biscuits obtained with the addition of psyllium flour.

\section{MATERIALS AND METHODS}

\section{Materials}

The flour from Plantago psyllium L. seeds was purchased in Natura24.pl. (with the following parameters: moisture $8.73 \mathrm{~g} / 100 \mathrm{~g}$, protein $5.35 \mathrm{~g} / 100 \mathrm{~g}(\mathrm{~N} \times 5.7)$, fat $1.88 \mathrm{~g} / 100 \mathrm{~g}$, dietary fibre $66.35 \mathrm{~g} / 100 \mathrm{~g}$ including insoluble $49.92 \mathrm{~g} / 100 \mathrm{~g}$ and soluble $16.43 \mathrm{~g} / 100 \mathrm{~g}$, total carbohydrates $79.27 \mathrm{~g} / 100 \mathrm{~g}$ ). Pastry wheat flour (type 550) was purchased from the Polish Cereal Plant PZZ (Krakow, Poland) with the following parameters: moisture $10.20 \mathrm{~g} / 100 \mathrm{~g}$, fat $1.87 \mathrm{~g} / 100 \mathrm{~g}$, proteins $9.05 \mathrm{~g} / 100 \mathrm{~g}(\mathrm{~N} \times 5.7)$, ash

\footnotetext{
*Corresponding author:

Magdalena Krystyjan, Ph.D., University of Agriculture, Balicka Street 122, 30-149 Krakow, Poland.

E-mail: m.krystyjan@gmail.com, magdalena.krystyjan@urk.edu.pl

Received: 11 February 2018; $\quad$ Accepted: 14 June 2018
} 
$0.31 \mathrm{~g} / 100 \mathrm{~g}$, soluble dietary fibre $0.41 \mathrm{~g} / 100 \mathrm{~g}$, insoluble dietary fibre $0.53 \mathrm{~g} / 100 \mathrm{~g}$, total dietary fibre $0.94 \mathrm{~g} / 100$ and total carbohydrate $77.94 \mathrm{~g} / 100 \mathrm{~g}$. Potato starch, baking powder, vanilla flavoured sugar, sucrose powder, eggs, margarine, milk (1.5\% fat) and salt were purchased from the local market.

\section{Preparation of dough and baking biscuits}

The basic formulation of biscuit dough was summarized in Table 1. The procedure of its preparation was taken from our previous work Krystyjan et al. (2015a). The wheat flour was substituted with psyllium flour in the amount: 0 , $5,10,15$ and $20 \%$ in relation to wheat flour. Each replicate (biscuit) was obtained from separately prepared batches of dough. The analyses were carried out on fresh biscuits (on the day of baking).

\section{Chemical analyses of biscuits}

The chemical compositions of biscuits (fat, protein, ash, and dietary fibre: soluble, insoluble and total dietary fibre) were carried out according to the AOAC (2006) methods. Total carbohydrate content was calculated from difference. Calorie value were calculated according to the Atwater system (FAO, 2002). The results were given as the average of three replicates.

\section{Spread ratio of biscuits}

The spread ratio of biscuits was measured according to Ajila et al (2008) procedure, dividing diameter of six biscuits by their thickness.

\section{Volume of biscuits}

The volume of biscuits was measured with laser volume meter Volscan profiler 600 (Stable Micro Systems, England). The results were given as the average of three replicates.

\section{Colour of biscuits}

The upper surface colour of biscuits was carried out with the use of Konica MINOLTA CM-3500d equipment (Konica Minolta Inc., Tokyo, Japan), with reference to illuminant D65 and a visual angle of $10^{\circ}$, using the CIELab system. The following parameters were determined: L*

\begin{tabular}{|c|c|c|c|c|c|}
\hline Components (g) & Control & B5 & B10 & B15 & B20 \\
\hline Wheat flour & 100.0 & 95.0 & 90.0 & 85.0 & 80.0 \\
\hline Sugar powder & 17.8 & 17.8 & 17.8 & 17.8 & 17.8 \\
\hline Potato starch & 11.5 & 11.5 & 11.5 & 11.5 & 11.5 \\
\hline Margarine & 24.1 & 24.1 & 24.1 & 24.1 & 24.1 \\
\hline Eggs & 4.6 & 4.6 & 4.6 & 4.6 & 4.6 \\
\hline Milk & 29.9 & 29.9 & 29.9 & 29.9 & 29.9 \\
\hline Salt & 0.3 & 0.3 & 0.3 & 0.3 & 0.3 \\
\hline Baking powder & 3.3 & 3.3 & 3.3 & 3.3 & 3.3 \\
\hline Plantago psyllium & 0.0 & 5.0 & 10.0 & 15.0 & 20.0 \\
\hline
\end{tabular}

Emir. J. Food Agric • Vol $30 \bullet$ Issue $9 \bullet 2018$
( $\mathrm{L}^{*}=0$ black, $\mathrm{L}^{*}=100$ white), $\mathrm{a}^{*}$ - share of the green colour $\left(a^{*}<0\right)$ or red $\left(a^{*}>0\right), b^{*}$ - share of blue $\left(b^{*}<0\right)$ or yellow $\left(b^{*}>0\right)$. The experiment was repeated four times.

\section{The textural properties of biscuits}

The measurements were determined using the TA-XT plus texture analyzer (Stable Micro Systems, Haslemere, $\mathrm{UK})$. The penetration test was performed using a P/6 cylinder probe, moving at $1 \mathrm{~mm}$ per second at a distance of $20 \mathrm{~mm}$, so that a hole was made through the biscuit. Hardness, as the value of maximum force was calculated. The experiment was repeated ten times.

\section{Sensory analysis of biscuits}

The evaluation was performed by a panel of 7 women and 6 men that were between the ages of 25 and 55, and of appropriate sensory sensitivity (PN-ISO 8586-1:1996). The quality descriptors and weighting coefficients to a fivepoint evaluation scale were chosen by assessors according to the procedure included in PN-ISO 6658:1998. Quality descriptors and weighting coefficients were chosen: shape $(0.1)$, colour $(0.1)$, surface $(0.15)$, consistency $(0.15)$, fracture $(0.1)$, aroma $(0.15)$ and taste $(0.25)$. The evaluation was based on the comparison made of these quality descriptors with those defined in the standard table (Krystyjan et al. 2015a).

\section{Statistical analyses}

The experimental data were subjected to one-way analysis of variance (ANOVA) using Statistica v. 8.0 software (Statsoft, Inc., Tulsa, OK, USA). The least significant difference, at the confidence level of 0.05, using Fisher tests were calculated.

\section{RESULTS AND DISCUSSION}

\section{Chemical composition of biscuits}

Considering the chemical composition of psyllium flour it has been confirmed that it was a rich source of dietary fibre $(66.35 \mathrm{~g} / 100 \mathrm{~g})$, of which $75 \%$ was an insoluble fraction and $25 \%$ a soluble fraction (Table 2). This flour contained also a large amount of carbohydrates $(79.27 \mathrm{~g} / 100 \mathrm{~g})$ and low protein and fat. Due to the high fibre content, it was reasonable to use this flour for baking biscuits in order to enrich them in the health-promoting nutrient. Table 2 presents the chemical composition and the calorific value of wheat biscuits fortified with psyllium flour. It was found that the fat and carbohydrates content in wheat biscuits with the use of psyllium flour did not change, regardless of the additive amount used, in comparison with control sample. The protein content of the fortified biscuits decreased from 4.5 to $13 \%$ compared to the control one. This should be explained by the fact that psyllium 
flour contained $50 \%$ less protein than substituted wheat flour. Quite opposite was the fact that the content of ash increased by $9 \%$ on average in fortified biscuits. It was associated with a high content of ash in the psyllium flour itself, which enriched the product in these important for human health ingredients. Mineral compounds do not only play a regulatory and hematopoietic role, but also affect the human's antioxidant balance due to the fact that they are co-factors of human antioxidant barrier enzymes (CastilloDurán \& Cassorla 1999).

Another very important health-related compound was dietary fibre. Considering the insoluble (IDF), soluble (SDF) and total dietary fibre (TDF), there was a gradual increase in this components in fortified biscuits in relation to the control (Table 2). This increase was adequate to the amount of psyllium flour and ranged from 30 to 596\% for insoluble fibre and from 67 to $374 \%$ for soluble fibre, respectively. In the case of total dietary fibre, the lowest content of the addition in biscuits (B5) contributed to a $50 \%$ increase in this parameter, and the highest level of the additive (B20) caused a 6-fold increase. It should be stressed that the psyllium flour a valuable source of fibre and guarantee the beneficial properties of the biscuits from a nutritional point of view. It may be added that the soluble fraction shows both hypocholesterolemic and hypoglycaemic abilities. Whereas the insoluble fraction modulates intestinal peristalsis and protects against cancer (Elleuch et al. 2011). Raymundo et al. (2014) research concerning the effect of fibre from psyllium on the chemical composition of biscuits reported that there were the reduction of protein content and no changes in fat content. The authors stated also the significant increase in fibre content. What is more, a significant increase in total dietary fibre content, as well as its soluble and insoluble fraction in biscuits enriched with mango peels was also noted (Ajila et al. 2008). The same authors observed a 3 -fold increase in TDF, IDF and SDF in biscuits with a $20 \%$ share of mango peel. In the case of this publication biscuit fortified with $20 \%$ of psyllium flour guaranteed a six-fold increase in these health-promoting ingredients. Hooda and Jood (2005) observed constant content of lipid, ash, increase of protein and decrease of carbohydrates in biscuits with fenugreek flour. The increase in protein content, fat and decrease in carbohydrates were observed by Mesías et al. (2016) in biscuits with chia flour. In the Krishnan et al. (2011) research on biscuits with finger millet seed coat showed no changes in protein and fat content, as well as carbohydrates decrease in the above-mentioned product in relation to control biscuits. At the same time, it was noticed that the addition of these seeds caused the increase of TDF (4-fold), IDF (3-6-fold) and SDF (2-fold) in fortified biscuits in relation to control. Mesías et al. (2016) also observed the TDF increase in biscuits, in which $20 \%$ level of chia flour addition guaranteed 4 -fold increase of this component in biscuits. Therefore it can be concluded that the psyllium flour among of discussed additives (mango peel, finger millet seed coat and chia flour) caused the greatest increase in dietary fibre in view of a large proportion of this fibre in the flour used for fortification. Moreover, the psyllium flour increased the health value of biscuits, effectively reducing their caloric value (Table 2).

\section{Spread ratio of biscuits}

The smallest spread ratio was characterized by control biscuits and those with 5 and 10\% addition of psyllium flour, between which there were no statistically significant differences (Table 3). The increase in spreadability in the remaining samples was 7 and 19\% for biscuits B15 and B20, respectively. The spreadability of biscuits is strongly correlated with the viscosity of the dough (Pareyt and Delcour 2008) and is decisively influenced by the amount of gluten prescribed in the recipe (Zouari et al., 2016). The substitution of wheat flour with psyllium flour limited the amount of gluten in the dough and additionally increased amount of fibre in the formula, which weakened the structure of the biscuit dough, contributing to its greater spreadability.

\section{Volume of biscuits}

Table 3 showed the results of the biscuits' volume. It was found that the $5 \%$ share of psyllium flour did not have a statistically significant effect on the volume of biscuits. In turn, with a $10 \%$ share of this flour (B10), the volume of biscuits decreased by $14 \%$ compared to the control. Further fortification of biscuits: B15 and B20 influenced the 28 and $39 \%$ volume reduction, respectively. The less amount of

Table 2: The content of nutrients, fibre, and calorific value of fresh baked biscuits

\begin{tabular}{|c|c|c|c|c|c|c|c|c|}
\hline \multirow[t]{2}{*}{ Sample } & \multirow{2}{*}{$\begin{array}{c}\text { Fat } \\
\text { [g/100g d.m.] }\end{array}$} & \multirow{2}{*}{$\begin{array}{c}\text { Total } \\
\text { carbohydrate } \\
\text { [g/100g d.m.] }\end{array}$} & \multirow{2}{*}{$\begin{array}{c}\text { Protein } \\
\text { [g/100g d.m.] }\end{array}$} & \multirow{2}{*}{$\begin{array}{c}\text { Ash } \\
\text { [g/100g d.m.] }\end{array}$} & \multicolumn{3}{|c|}{ Dietary fibre [g/100g d.m.] } & \multirow{2}{*}{$\begin{array}{c}\text { Calorific value } \\
\text { [kcal/100g] }\end{array}$} \\
\hline & & & & & Insoluble & Soluble & Total & \\
\hline Control & $12.96 \pm 0.20^{\mathrm{a}}$ & $70.49 \pm 0.30^{a}$ & $7.96 \pm 0.10^{\mathrm{a}}$ & $1.65 \pm 0.01^{c}$ & $1.22 \pm 0.01^{\mathrm{e}}$ & $1.13 \pm 0.01^{\mathrm{e}}$ & $2.35 \pm 0.01^{e}$ & $414 \pm 1^{\mathrm{a}}$ \\
\hline B5 & $12.74 \pm 0.24^{\mathrm{a}}$ & $69.83 \pm 1.14^{\mathrm{ab}}$ & $7.60 \pm 0.01^{b}$ & $1.83 \pm 0.01^{\mathrm{a}}$ & $1.59 \pm 0.02^{\mathrm{d}}$ & $1.89 \pm 0.04^{d}$ & $3.48 \pm 0.06^{d}$ & $399 \pm 2^{b}$ \\
\hline B10 & $13.04 \pm 0.02^{\mathrm{a}}$ & $68.28 \pm 0.36^{b}$ & $7.11 \pm 0.00^{c}$ & $1.82 \pm 0.01^{\mathrm{a}}$ & $2.79 \pm 0.02^{c}$ & $2.47 \pm 0.03^{c}$ & $5.26 \pm 0.01^{c}$ & $379 \pm 2^{c}$ \\
\hline B15 & $12.89 \pm 0.08^{a}$ & $68.74 \pm 1.03^{\mathrm{ab}}$ & $7.13 \pm 0.06^{c}$ & $1.74 \pm 0.02^{b}$ & $5.82 \pm 0.02^{b}$ & $3.49 \pm 0.02^{b}$ & $9.31 \pm 0.04^{b}$ & $347 \pm 3^{d}$ \\
\hline B20 & $12.97 \pm 0.05^{\mathrm{a}}$ & $68.44 \pm 0.15^{\mathrm{ab}}$ & $6.90 \pm 0.09^{d}$ & $1.83 \pm 0.03^{\text {a }}$ & $8.50 \pm 0.03^{a}$ & $5.36 \pm 0.06^{a}$ & $13.86 \pm 0.09^{a}$ & $308 \pm 1^{e}$ \\
\hline
\end{tabular}

Parameters in columns denoted with the same letters do not differ statistically at the level of confidence 0.05 . 
gluten present in the recipe was responsible for the decrease in the volume of supplemented biscuits, just as in the case of spread ratio. Fortification reduced the amount of wheat flour and hence the amount of gluten in the biscuits, so the structure of the formed gluten network was weaker.

In addition, gluten swelling could be limited by the mucilaginous substances presented in psyllium flour (Craeyveld et al. 2009) with strong hydrophilic properties (Guo et al. 2008). The main constituent of the mucilage is the heteropolysaccharide with a complex structure whose basic units are arabinose and xylose molecules (Craeyveld et al 2009, Guo et al. 2008) Thanks to its strong waterbinding properties, the mucilage contained in the psyllium flour competed with the wheat flour for water molecules. As the amount of liquid components in the formula was constant, therefore, the increased amount of mucilage in the fortified biscuits additionally limited swelling of gluten in the wheat flour.

\section{Texture of biscuits}

The biscuits with the addition of psyllium flour were characterized by lower hardness compared to the control (Table 3). Significant differences were observed already at the smallest addition of psyllium flour (B5 and B10), by about 20 and $28 \%$, respectively. In the case of a greater share of psyllium flour B15 and B20, this decrease was even greater than $50 \%$, which affected the sensory evaluation of the fortified biscuits. The decrease in the hardness of fortified biscuits was related with the increasing content of dietary fibre in them, which was confirmed by Arun et al. (2015) after introducing the peel fibre into biscuits. Sharma and Gujral (2014) and Korus et al. (2017) found that the strongly hydrophilic components absorb a lot of water, which at its constant content in the biscuits recipe leads to a harder dough. The consequence of hard dough may be a reduction in the volume of biscuits and an increase in their hardness. However, as shown in the present study, the introduction of psyllium flour, with a high content of mucilage and other hydrophilic ingredients resulted in a reduction of the product volume. On the other hand, it did not contribute to the increase in the hardness of biscuits, on the contrary, it decreased this parameter. The reason of it was the fact that besides a significant amount of highly hydrophilic substances presented in the psyllium flour, there was also a large amount of dietary fibre. In addition, the fortification process itself contributed to reducing the amount of protein in the product, as well as the amount of gluten, which was responsible for giving and maintaining the structure of biscuits.

\section{Colour of biscuits}

The colour of the product is one of the first factors influencing consumer decision. In the production of biscuits, the colour is created in the last baking stage and is made with the Maillard reaction (Wade 1988). Analysing the colour of biscuits, it was observed that their fortification significantly darkened the surface of biscuits when compared to the control (Table 3). The $\mathrm{L}^{*}$ values of $\mathrm{B} 5$ and B1 biscuits was 8 and $9 \%$, respectively lower than in control sample (Table 3). The addition of psyllium flour successively reduced this parameter, as a result of which the maximum addition of this flour (B20) caused a 21\% reduction in $\mathrm{L}^{*}$ values. All samples (also control) had a higher share of red $\left(a^{*}>0\right)$ and yellow $\left(b^{*}>0\right)$ colour. It is consistent with the assumptions of Köksel and Gökmen (2008), that during backing process the lightness parameter tends to decrease and the chromatic parameters increase. However, in this work, it was noticed that the fortified biscuits had lower values of chromatic parameters than the control ones and these parameters decreased along with the increasing share of psyllium flour in biscuits. The minimal contribution of the psyllium flour (B5) led to $18 \%$ decrease in the $\mathrm{a} *$ and $\mathrm{b} *$ parameters relative to the control. However, when the largest fortification (B20) was applied this decrease was over $30 \%$. The changes in the colour of fortified biscuits resulted from two factors. The first and dominant was the color of the psyllium flour, which was characterized by a greyish shade and strongly affected the overall colour of the dough and biscuits. This was also noticed by the panelists. On the other hand, when comparing the chemical composition of wheat and psyllium flour, it was stated that the wheat flour was characterized by a higher protein content, which had a significant impact on the Maillard reaction during baking.

\section{Sensory parameters of biscuits}

The results of the sensory evaluation are presented in Table 4. According to these data, a 5\% share of the psullium flour in place of wheat allow maintaining good sensory characteristics

Table 3: Physical parameters of biscuits

\begin{tabular}{|c|c|c|c|c|c|c|}
\hline \multirow[t]{2}{*}{ Sample } & \multirow[t]{2}{*}{ Spread ratio } & \multirow[t]{2}{*}{ Volume $(\mathrm{ml})$} & \multirow{2}{*}{$\begin{array}{c}\text { Texture } \\
\text { Hardness (N) }\end{array}$} & \multicolumn{3}{|c|}{ Colour } \\
\hline & & & & $L^{*}$ & $a^{*}$ & $\mathbf{b}^{*}$ \\
\hline Control & $5.19 \pm 0.38^{c}$ & $74.4 \pm 4.9^{a}$ & $23.47 \pm 4.33^{a}$ & $72.08 \pm 0.89^{a}$ & $6.71 \pm 0.45^{\mathrm{a}}$ & $33.72 \pm 0.54^{a}$ \\
\hline B5 & $5.20 \pm 0.10^{c}$ & $72.8 \pm 4.0^{a}$ & $18.86 \pm 3.30^{b}$ & $66.12 \pm 2.14^{\mathrm{b}}$ & $5.51 \pm 1.07^{b}$ & $27.67 \pm 1.53^{b}$ \\
\hline B10 & $5.38 \pm 0.43^{\mathrm{bc}}$ & $64.1 \pm 1.1^{\mathrm{b}}$ & $16.94 \pm 0.97^{b}$ & $65.54 \pm 0.64^{b}$ & $4.01 \pm 0.14^{c}$ & $21.41 \pm 0.45^{d}$ \\
\hline B15 & $5.55 \pm 0.44^{b}$ & $53.6 \pm 3.2^{c}$ & $12.67 \pm 3.78^{c}$ & $61.03 \pm 0.57^{c}$ & $4.39 \pm 0.32^{c}$ & $22.87 \pm 0.32^{c}$ \\
\hline B20 & $6.18 \pm 0.34^{a}$ & $45.5 \pm 0.5^{d}$ & $7.54 \pm 0.96^{d}$ & $56.84 \pm 0.60^{d}$ & $4.66 \pm 0.32^{c}$ & $21.91 \pm 0.37^{c d}$ \\
\hline
\end{tabular}

Parameters in columns denoted with the same letters do not differ statistically at the level of confidence 0.05 . 
Table 4: The scores of sensory analysis of biscuits

\begin{tabular}{|c|c|c|c|c|c|c|c|c|}
\hline Sample & $\begin{array}{l}\text { Shape } \\
x(0.1)\end{array}$ & $\begin{array}{l}\text { Colour } \\
\times(0.1)\end{array}$ & $\begin{array}{l}\text { Surface } \\
\mathrm{x}(0.15)\end{array}$ & $\begin{array}{c}\text { Consistency } \\
\text { x (0.15) }\end{array}$ & $\begin{array}{c}\text { Fracture } \\
\times(0.1)\end{array}$ & $\begin{array}{l}\text { Aroma } \\
\mathrm{x}(0.15)\end{array}$ & $\begin{array}{c}\text { Taste } \\
\times(0.25)\end{array}$ & Total score \\
\hline Control & $0.5 \pm 0.0^{a}$ & $0.5 \pm 0.0^{a}$ & $0.8 \pm 0.0^{a}$ & $0.9 \pm 0.1^{a}$ & $0.4 \pm 0.1^{\mathrm{a}}$ & $0.5 \pm 0.0^{a}$ & $1.3 \pm 0.2^{\mathrm{ab}}$ & $4.9 \pm 0.3^{a}$ \\
\hline O5 & $0.5 \pm 0.0^{a}$ & $0.5 \pm 0.1^{\mathrm{a}}$ & $0.7 \pm 0.1^{\mathrm{ab}}$ & $0.8 \pm 0.1^{a}$ & $0.4 \pm 0.1^{a}$ & $0.4 \pm 0.1^{a}$ & $1.3 \pm 0.2^{\mathrm{ab}}$ & $4.6 \pm 0.5^{\mathrm{a}}$ \\
\hline 010 & $0.4 \pm 0.1^{\mathrm{a}}$ & $0.3 \pm 0.1^{b}$ & $0.6 \pm 0.1^{b c}$ & $0.7 \pm 0.2^{\mathrm{ab}}$ & $0.4 \pm 0.1^{\mathrm{a}}$ & $0.4 \pm 0.1^{\mathrm{a}}$ & $1.1 \pm 0.3^{b c}$ & $3.9 \pm 0.5^{b}$ \\
\hline 015 & $0.4 \pm 0.1^{a}$ & $0.3 \pm 0.1^{b}$ & $0.5 \pm 0.1^{c}$ & $0.6 \pm 0.1^{b}$ & $0.3 \pm 0.1^{a}$ & $0.4 \pm 0.1^{a}$ & $1.0 \pm 0.2^{c}$ & $3.5 \pm 0.5^{b c}$ \\
\hline $\mathrm{O} 20$ & $0.4 \pm 0.1^{\mathrm{a}}$ & $0.3 \pm 0.1^{b}$ & $0.3 \pm 0.1^{d}$ & $0.6 \pm 0.1^{b}$ & $0.3 \pm 0.1^{\mathrm{a}}$ & $0.4 \pm 0.1^{\mathrm{a}}$ & $0.9 \pm 0.3^{c}$ & $3.1 \pm 0.3^{c}$ \\
\hline
\end{tabular}

Parameters in columns denoted with the same letters do not differ statistically at the level of confidence 0.05 .

at a level acceptable for consumers. Increasing the share of psullium flour (over 10\% in relation to wheat flour) significantly worsened the overall sensory evaluation of the product. On the surface of the biscuits with 15 and 20\% addition of psyllium cracks were observed, which was reflected in the low rating for the surface (below 0.3). This phenomenon results from too high amount of fibre incorporated instead of wheat flour and with the reduction of protein, which was mentioned in the previous analysis of biscuits. The consistency of B15 and B20 biscuits was equally low, as confirmed by textural results. According to the panelists, the addition of psyllium flour (not more than 5\%) had a positive effect on the colour of the product, which was as attractive in their opinion, as the color of the control biscuits. Above this value $(>5 \%)$, the product was too greyish, which was mainly responsible for the color of the flour psyllium itself, which the panelists thought was less desirable. The addition of psyllium flour, in turn, did not affect the aroma and shape of the samples. All in all, it can be concluded that the fortification of biscuit with psyllium flour is only possible up to $5 \%$ and above this value the sensory attributes of the product deteriorated.

\section{CONCLUSIONS}

It was found that the fortification of biscuits with psyllium flour seems to be justified. This treatment allowed to enrich biscuits not only in dietary fibre, which psyllium flour is a good source of, but also in minerals. However, as it was confirmed by sensory analyses, above $10 \%$ of the psyllium flour addition to the biscuit, the quality parameters of the product significantly deteriorated. In above 15\% share of this flour, the surface of baked biscuits cracked and the colour deteriorated (was too greyish in panelists opinion). Along with the increasing proportion of psyllium flour in biscuits, their spreadability increased, while the volume and hardness decreased. Considering all the above-mentioned features, it seems that $5 \%$ psyllium flour fortification in biscuits is recommendable.

\section{ACKNOWLEDGEMENTS}

This research was financed by the Ministry of Science and Higher Education of the Republic of Poland. Special grant: BM- 4712/KTW/2016.

\section{ABBREVIATIONS}

TDF - Total dietary fibre,

IDF - insoluble dietary fibre,

SDF- soluble dietary fibre

B5 - wheat flour was substituted with psyllium flour in the amount $5 \%$

B10 - wheat flour was substituted with psyllium flour in the amount $10 \%$

B15 - wheat flour was substituted with psyllium flour in the amount $15 \%$

B20 - biscuits in which wheat flour was substituted with psyllium flour in the amount $20 \%$

\section{CONFLICT OF INTEREST}

None

\section{REFERENCES}

Ajila, C. M., K. Leelavathi and R. U. J. S. Prasada. 2008. Improvement of dietary fiber content and antioxidant properties in soft dough biscuits with the incorporation of mango peel powder. J Cereal Sci. 48: 319-326.

Aggarwal, D., L. Sabikhi, M. H. S. Kumar. 2016. Formulation of reduced-calorie biscuits using artificial sweeteners and fat replacer with dairy-multigrain approach. NFS J. 2: 1-7.

AOAC. 2006. Official Methods of Analysis. $18^{\text {th }}$ ed. Association of Official Analytical Chemists International, Gainthersburg, MD.

Arun, K. B., F. Persia, P. S. Aswathy, J. Chandran, M. S. Sajeev, P. Jayamurthy and P. Nisha. 2015. Plantain peel-a potential source of antioxidant dietary fibre for developing functional cookies. J Food Sci Technol. 52(10): 6355-6364.

Castillo-Durán, C., F. Cassorla. 1999. Trace minerals in human growth and development. J Pediatr Endocrinol Metab. 12: 589-601.

Chauhan, A., D. Saxena and S. Singh. 2015. Total dietary fibre and antioxidant activity of gluten free cookies made from raw and germinated amaranth (Amaranthus spp.) flour. LWT-Food Sci Technol. 63(2): 939-945.

Craeyveld, V. V., J. A. Delcour and C. M. Courtin. 2009. Extractability, chemical and enzymatic degradation of psyllium (Plantago ovata Forsk) seed husk arabinoxylans. Food Chem. 112: 812-819.

Čukelj, N., D. Novotni, H. Sarajlija, S. Drakula, B. Voučko and D. Ćurić. 2017. Flaxseed and multigrain mixtures in the development of functional biscuits. LWT-Food Sci Technol. 86: 85-92.

Elleuch, D., D. Bedigian, O. Roiseux, S. Besbes, C. Blecker and H. Attia. 2011. Dietary fibre and fibre-rich by-products of food 
processing: Characterisation, technological functionality and commercial applications: A review. Food Chem. 124: 411-421.

FAO. 2002. Food energy. Methods of analysis and conversion factors. Food and Nutrition Paper 77. Report of a technical workshop, Rome 3-6 December. ISSN 0254-4725.

Guo, Q., S. W. Cui, Q. Wang and J. C. Young. 2008. Fractionation and physicochemical characterization of psyllium gum. Carbohyd Polym. 73: 35-43.

Hooda, S and S. Jood. 2005. Organoleptic and nutritional evaluation of wheat biscuits supplemented with untreated and treated fenugreek flour. Food Chem. 90: 427-435.

Korus, A., D. Gumul, M. Krystyjan and J. Korus. 2017. Evaluation of the quality, nutritional value and antioxidant activity of glutenfree biscuits made from corn-acorn flour or corn-hemp flour composites. Eur Food Res Technol. 243(8): 1429-1438.

Köksel, H and V. Gökmen. 2008. Chemical reaction in the processing of soft wheat products. In: Şumnu S. G and S. Sahir, (Eds). Food Engineering Aspects of Backing Sweet Goods. CPC Press Taylor and Francis Group, New York.

Krishnan, R., U. Dhamaraj, R. S. Manohar and N. G. Malleshi. 2011. Quality characteristics of biscuits prepared from finger millet seed coat based composite flour. Food Chem. 129: 499-506.

Krystyjan, M., G. Khachatryan, W. Ciesielski, K. Buksa and M. Sikora. 2017. Preparation and characteristics of mechanical and functional properties of starch/Plantago psyllium seeds mucilage films. Starch/Stärke. 69: DOI 10.1002/star.201700014.

Krystyjan, M., D. Gumul, R. Ziobro and A. Korus. 2015a. The fortification of biscuits with bee pollen and its effect on physicochemical and antioxidant properties in biscuits. LWTFood Sci Technol. 63: 640-646.

Krystyjan, M., D. Gumul, R. Ziobro and M. Sikora M. 2015b. The effect of inulin as a fat replacement on dough and biscuit properties. $J$ Food Qualit. 38: 305-315.

Laguna, L., P. Varea, A. Salvador, T. Sanz and S. M. Fiszman. 2012. Balancing texture and other sensory features in reduced fat short-dough biscuits. J Texture Stud. 43: 235-245.

Mesías, M., F. Holgado, G. Márquez-Ruiz and F. J. Morales. 2016. Risk/benefit considerations of a new formulation of wheat-based biscuit supplemented with different amounts of chia flour. LWTFood Sci Technol. 73: 528-535.

Osheba, A. S., S. A. Hussien and A. A. El-Dashlouty. 2013. Evaluation of some vegetal colloids on the quality attributes of beef sausage. Adv. J. Food Sci. Technol. 5: 743-751.

Pareyt, B and J. A. Delcour. 2008. The role of wheat flour constituents sugar, and fat in low moinsture cereal based products. A review on sugar-snap cookies. Crit Rev Food Sci Nutr. 48: 824-839.

Pasqualone, A, A. M. Bianco, V. M. Paradiso, C. Summo, G. Gambacorta and F. Caponio. 2014. Physico-chemical, sensory and volatile profiles of biscuits enriched with grape marc extract. Food Res Int. 65: 385-393.

PN-ISO 6658. 1998. Sensory analysis. Methodology. General guidance (in Polish).

PN-ISO 8586-1. 1996. Sensory Analysis-General Guidance for Selection, Training and Monitoring of Assessors-Part 1: Selected Assessors (in Polish).

Raymundo, A., P. Fradihno and M. C. Nunes. 2014. Effect of Psyllium fibre kontent on the textural and rheological characteristics of biscuit and biscuit dough. Bioact Carbohydr Diet Fibre. 3: 96-105.

Rodríguez-García, J., L. Laguna, A. Puig, A. Salvador and I. Hernando. 2013. Effect of fat replacement by inulin on textural and structural properties of short dough biscuits. Food Bioprocess Technol. 6(10): 2739-2750.

Savitha, Y. S., D. Indrani and J. Prakash. 2008. Effect of replacement of sugar with sucralose and maltodextrin on rheological characteristics of wheat flour dough and quality of soft dough biscuits. J Texture Stud. 39: 605-616.

Singh, B. 2007. Psyllium as therapeutic and drug delivery agent. Int $J$ Pharm Rev. 334: 1-14.

Sharma, P and H. S. Gujral. 2014. Cookie making behavior of wheatbarley flour blends and effects on antioxidant properties. LWTFood Sci Technol. 55(1): 301-307.

Tireki, S., Technology of Cookie Production. 2008. In: Şumnu, S. G and S. Sahir, (Eds). Food Engineering Aspects of Backing Sweet Goods. New York, CPC Press Taylor and Francis Group.

Wade, P. 1988. Biscuits, Cookies and Crackers, the Principles of the Craft. Vol. 1. Elsevier Applied Science, Publishers Ltd, London.

Zouari, R., S. Besbes, S. Ellouze-Chaabouni and D. Ghribi-Aydi. 2016. Cookies from composite wheat-sesame peels flours: Dough quality and effect of Bacillus subtilis SPB1 biosurfactant addition. Food Chem. 194: 758-769.

Zoulias, E. I., V. Oreopoulou and E. Kounalaki. 2002. Effect 